\title{
OCENA SPÓJNOŚCI TERYTORIALNEJ POD WZGLĘDEM SPOLECZNYM I GOSPODARCZYM PODREGIONÓW POLSKI
}

\author{
Streszczenie
}

Spójność terytorialna jest kategorią rozwoju przestrzeni w polityce europejskiej i krajowej. Celem artykułu jest ocena spójności terytorialnej podregionów Polski, której dokonano za pomocą metod wielowymiarowej analizy porównawczej. Umożliwiło to ocenę zróżnicowania i współbieżności poziomu rozwoju gospodarczego oraz rozwoju społecznego dla podregionów Polski. Przeanalizowano dane GUS z lat 2014-2015.

Słowa kluczowe: spójność społeczna, spójność gospodarcza, spójność terytorialna, polityka regionalna

\section{ASSESSMENT OF TERRITORIAL COHESION IN TERMS OF SOCIAL AND ECO- NOMIC SITUATION OF POLAND'S SUBREGIONS}

\begin{abstract}
Summary
Territorial cohesion is a category of space development in European and national policies. The purpose of the paper is to assess the territorial cohesion of Poland's subregions. Assessment of cohesion is conducted using methods of multidimensional comparative analysis. This enables the author to evaluate the diversity and interdependence of the levels of economic and social development of the subregions of Poland. Central Statistical Office (GUS) data from 2014-2015 have been analysed.
\end{abstract}

Key words: social cohesion, economic cohesion, territorial cohesion, regional policy

JEL classification: C1, C10, O, R 58

\section{Wstęp}

Integralnym komponentem polityki rozwoju jest polityka regionalna. Jest to świadoma i celowa działalność organów władzy publicznej zmierzająca do rozwoju regionalnego, który jest określany jako systematyczna poprawa konkurencyjności podmiotów gospodarczych i poziomu życia mieszkańców oraz wzrost rozwoju potencjału gospodarczego regionów, przyczyniający się do rozwoju społeczno-ekonomicznego 
kraju [Szlachta, 1999, s. 1]. Polityka regionalna stymuluje wykorzystanie potencjału rozwojowego, wspierając tworzenie tożsamości regionalnych (w sensie: społecznym, ekonomicznym i kulturowym).

Krajowa Strategia Rozwoju Regionalnego 2010-2020: Regiony, Miasta, Obszary wiejskie (KSRR) wnosi nowy sposób planowania rozwoju w wymiarze terytorialnym i programowania polityki regionalnej. W tym ujęciu polityka regionalna dąży do identyfikacji i skutecznego wykorzystania walorów regionów i ich możliwości rozwoju [Rynio, 2012, s. 395].

W Krajowej Strategii Rozwoju Regionalnego 2010-2020 sformułowano trzy poniższe cele szczegółowe.

1. Wspomaganie wzrostu konkurencyjności regionów („konkurencyjność”).

2. Budowanie spójności terytorialnej i przeciwdziałanie procesom marginalizacji na obszarach problemowych („,spójność).

3. Tworzenie warunków skutecznej, efektywnej i partnerskiej realizacji działań rozwojowych ukierunkowanych terytorialnie (,sprawność”) [Krajowa Strategia Rozwoju Regionalnego 2010-2020..., 2010, s. 86].

Zatem spójności terytorialna jest jednym z trzech celów szczegółowych Strategii Rozwoju Regionalnego. Celem artykułu jest ocena współbieżności w poziomie rozwoju gospodarczego i rozwoju społecznego, jak również zróżnicowania tych poziomów zmiennych dla podregionów Polski.

\section{Spójność w układzie regionalnym}

Zróżnicowanie regionalne jest przyczyną wszystkich działań podjętych w celu osiągnięcia spójności. Analizie podlegają różne rodzaje tej spójności: od gospodarczej i społecznej, do spójności terytorialnej będącej konsekwencją wcześniej wymienionych.

Pojęcie spójności gospodarczej jest wykorzystywane do wykazania nierówności gospodarczych pomiędzy regionami lub krajami. Badanie spójności społecznej regionów koncentruje się na: zjawiskach zachodzących na rynku pracy, technicznych możliwościach prowadzenia działalności gospodarczej i warunkach życia mieszkańców. Tymczasem analiza spójności terytorialnej pozwala ustalić pozycję regionu na tle innych obszarów, biorąc za podstawę relatywne znaczenie gospodarcze każdego z nich dla funkcjonowania terytorium jako całości [Greta, Tomczak-Woźniak, 2016 s. 5].

Ważnym elementem polityki regionalnej, który będzie służyć poprawie spójności regionu, jest Kontrakt Terytorialny. Jest to nowe narzędzie polityki rozwoju, którego zadaniem jest zwiększenie skuteczności tej polityki [https://www.mr.gov.pl/strony/ zadania/polityka-rozwoju-kraju/zarzadzanie-rozwojem-kraju/kontrakty-wojewódzkie]. Przykład tego narzędzia w stosunku do województwa opolskiego opisano poniżej.

Kontrakt Terytorialny na lata 2014-2023 zawarto pomiędzy ministrem infrastruktury i rozwoju a województwem opolskim, zwanym „Stroną samorządową”, reprezentowanym przez Zarząd Województwa. Celem kontraktu jest koordynacja działań, aby zwiększyć 
skuteczność i efektywność niżej wymienionych działań oraz efektywności wydatkowania środków publicznych, jak również zaangażowanie środków publicznych, europejskich i krajowych w działania z zakresu polityki rozwoju, które zgodnie z szacunkami, w latach 2014-2023, w skali całego kraju może wynieść około 400 mld zł, w tym w województwie opolskim około 10,1 mld zł [Kontrakt Terytorialny...].

Zadeklarowano wolę współpracy w szczególności przy realizacji następujących celów rozwojowych i kierunków działań na terenie województwa:

- $\quad$ poprawa jakości badań oraz wzmocnienie współpracy sektora nauki i gospodarki;

- $\quad$ rozwój powiązań transportowych regionu;

- budowa, rozbudowa i modernizacja istniejącej sieci elektroenergetycznej;

- $\quad$ zapobieganie negatywnym skutkom powodzi;

- $\quad$ zachowanie dziedzictwa kulturowego i naturalnego;

- $\quad$ zwiększenie poziomu zatrudnienia w województwie;

- redukcja poziomu wykluczenia społecznego;

- $\quad$ podniesienie poziomu wykształcenia i kompetencji w regionie;

- $\quad$ podniesienie jakości i dostępności usług z zakresu ochrony zdrowia;

- $\quad$ rozwój miasta wojewódzkiego, powiązanych z nim funkcjonalnie obszarów oraz miast regionalnych i subregionalnych;

- $\quad$ wsparcie rewitalizacji dzielnic i miast o wysokim nasileniu niekorzystnych zjawisk społecznych i gospodarczych [Kontrakt Terytorialny ...].

Kontrakty terytorialne są ważnym narzędziem polityki rozwoju dla każdego regionu i powinny wspomagać jej skuteczność. Każdy z regionów dzieli się jednak na podregiony, które mają swoją specyfikę i różnią się poziomem rozwoju. Podjęto zatem próbę oceny spójności na poziomie podregionów.

\section{Spójność w układzie podregionów (NTS 3)}

Najczęściej spójność jest pojęciem oznaczającym zgodność własności pewnych obiektów, ich podobieństwo do wzorca lub też zgodność przebiegu prowadzącą od jednego stanu do drugiego. Oznacza ona również łączenie w całość, czyli integrację poprzez kształtowanie powiązań [Churski, 2011, s. 99-108].

Przez pojęcie spójności rozumie się dążenie do wyrównywania różnic w poziomie rozwoju (konwergencja), lecz w układzie krajowym traktowane niejednoznacznie odnosi się głównie do wymiaru przestrzennego, bowiem chodzi przede wszystkim o niedopuszczenie do nadmiernych zróżnicowań przestrzennych (wewnątrz regionów, a także pomiędzy regionami) [Gospodarowicz, 2016, s. 4]. Posiłkując się tym pojęciem w układzie funkcjonalnym, wyróżnia się jej trzy wymiary, tj.: ekonomiczny, społeczny i terytorialny [Faludi, 2006, s. 667-678]. Spójność terytorialna ma charakter komplementarny w stosunku do pozostałych jej wymiarów.

W niniejszym artykule dokonano analizy spójności obszarów na poziomie pomiaru NTS 3 - 72 podregiony Polski. W opracowaniach spotyka się poziom pomiaru NTS 
2 (województwa) lub NTS 5 (gminy). W tabeli 1. wymieniono poszczególne obiekty - podregiony Polski.

TABELA 1.

Podział obszaru Polski na poziomie NTS 3 (podregiony)

\begin{tabular}{|c|c|c|}
\hline Województwo & dolnośląskie & kujawsko- pomorskie \\
\hline Podregion & $\begin{array}{l}\text { jeleniogórski, legnicko-głogowski, } \\
\text { wałbrzyski, wrocławski, m. Wrocław }\end{array}$ & $\begin{array}{l}\text { bydgosko-toruński, gru- } \\
\text { dziądzki, inowrocławski, } \\
\text { świecki, włocławski }\end{array}$ \\
\hline Województwo & lubelskie & lubuskie \\
\hline Podregion & $\begin{array}{l}\text { bialski, chełmsko-zamojski, lubelski, } \\
\text { puławski }\end{array}$ & gorzowski, zielonogórski \\
\hline Województwo & łódzkie & małopolskie \\
\hline Podregion & $\begin{array}{l}\text { łódzki, m. Łódź, piotrkowski, sie- } \\
\text { radzki, skierniewicki }\end{array}$ & $\begin{array}{l}\text { krakowski, m. Kraków, } \\
\text { nowosądecki, nowotar- } \\
\text { ski, oświęcimski, tarnow- } \\
\text { ski }\end{array}$ \\
\hline Województwo & mazowieckie & opolskie \\
\hline Podregion & $\begin{array}{l}\text { ciechanowski, ostrołęcki, płocki, ra- } \\
\text { domski, siedlecki, m. st. Warszawa, } \\
\text { warszawski wschodni, warszawski za- } \\
\text { chodni }\end{array}$ & nyski, opolski \\
\hline Województwo & podkarpackie & podlaskie \\
\hline Podregion & $\begin{array}{l}\text { krośnieński, przemyski, rzeszowski, } \\
\text { tarnobrzeski }\end{array}$ & $\begin{array}{l}\text { białostocki, łomżyński, } \\
\text { suwalski }\end{array}$ \\
\hline Województwo & pomorskie & śląskie \\
\hline Podregion & $\begin{array}{l}\text { chojnicki, gdański, słupski, staro- } \\
\text { gardzki, trójmiejski }\end{array}$ & $\begin{array}{l}\text { bielski, bytomski, często- } \\
\text { chowski, gliwicki, kato- } \\
\text { wicki, rybnicki, sosno- } \\
\text { wiecki, tyski }\end{array}$ \\
\hline Województwo & świętokrzyskie & warmińsko-mazurskie \\
\hline Podregion & kielecki, sandomiersko-jędrzejowski & elbląski, ełcki, olsztyński \\
\hline Województwo & wielkopolskie & zachodniopomorskie \\
\hline Podregion & $\begin{array}{l}\text { kaliski, koniński, leszczyński, pilski, } \\
\text { poznański, m. Poznań }\end{array}$ & $\begin{array}{l}\text { koszaliński, m. Szczecin, } \\
\text { szczecinecko-pyrzycki, } \\
\text { szczeciński }\end{array}$ \\
\hline
\end{tabular}

Nomenklatura Jednostek Terytorialnych dla Celów Statystycznych (NTS), The Nomenclature of Territorial Units for Statistics (NUTS) - jednolity schemat podziału terytorialnego krajów Unii Europejskiej. W Polsce zastosowana Rosporzadzeniem Rady Ministrów z dnia 13 lipca 2000 roku w spranie wprowadzenia Nomenklatury Jednostek. Terytorialnych do Celów Statystycznych (NTS) (Dz. U. Nr 58, poz. 685 z późn. zm.).

Źródło: [Rocznile statystycżyy województow, 2015, s. 92-163]. 
Rysunek 1. obrazuje podział terytorium Polski na 72 podregiony.

RYSUNEK 1.

\section{Podział Polski na poziomie NTS 3 (podregiony)}

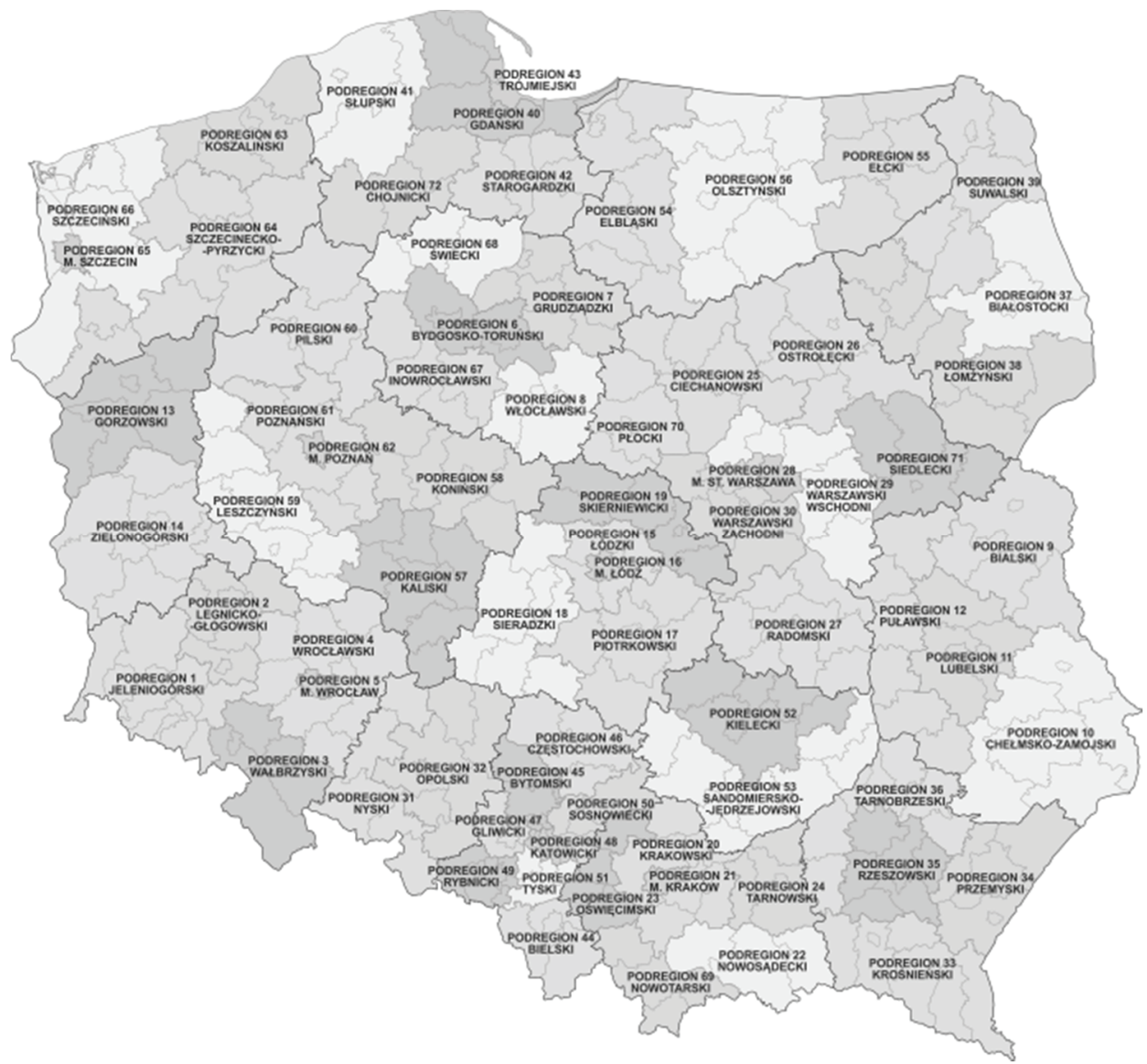

Źródło: [http://stat.gov.pl/statystyka-regionalna/jednostki-terytorialne/nomenklatura-nts/].

Okres badawczy (rok 2014 i 2015) został wymuszony względami przyjętej metody badawczej. Wielowymiarowość badanych zjawisk, agregacja zmiennych je opisujacych, ale również porównanie współbieżności i zmian w zróżnicowaniu wymagały danych o tej samej liczebności badanych obiektów. W poprzednich latach liczba podregionów Polski wynosiła 66. Następnie liczba podregionów uległa zwiększeniu. Dane GUS z okresu 2014 i 2015 ukazuja podział na poziomie NTS 3 na 72 podregiony. Nazwy „,nowych” podregionów zaznaczono w tabeli 1. 
TABELA 2.

Zmienne diagnostyczne - pomiar poziomu rozwoju gospodarczego

\begin{tabular}{|l|l|}
\hline \multicolumn{1}{|c|}{ Nazwa zmiennej } & Numer \\
\hline Nakłady inwestycyjne w przedsiębiorstwach według lokalizacji inwestycji (ceny & $X_{1}$ \\
bieżące) na 1 mieszkańca & \\
PKB brutto na 1 mieszkańca & $X_{2}$ \\
Pracujący w usługach i pozostałych usługach (odsetek wszystkich pracujących) & $X_{3}$ \\
Podmioty gospodarki narodowej w rejestrze REGON na 10 tys. mieszkańców & $X_{4}$ \\
\hline
\end{tabular}

Źródło: [Rocznike statystyczny wojewódz̦tw, 2015, s. 92- 163; Rocznike statystyczny wojewódẓtw, 2014, s. 92-163].

Badając spójność obiektów (podregionów), zaproponowano jedenaście zmiennych diagnostycznych, określających za pomocą wskaźników poziom rozwoju gospodarczego (tabela 2.) i poziom rozwoju społecznego (tabela 3.).

TABELA 3.

Zmienne diagnostyczne - pomiar poziomu rozwoju społecznego

\begin{tabular}{|l|l|}
\hline \multicolumn{1}{|c|}{ Nazwa zmiennej } & Numer \\
\hline Zmiana liczby ludności & $X_{5}$ \\
Wskaźnik obciążenia demograficznego* $^{*} X_{6}$ \\
Wskaźnik obciążenia społecznego** $^{*}$ & $X_{7}$ \\
Gęstość zaludnienia & $X_{8}$ \\
Saldo migracji na pobyt stały na 10 tys. ludności & $X_{9}$ \\
Przyrost naturalny na 1 tys. ludności & $X_{10}$ \\
Miejsca w domach i zakładach pomocy społecznej na 10 tys. mieszkańców & $X_{11}$ \\
\hline
\end{tabular}

* Zmienne dotyczące obciążenia demograficznego nie wykazywały żadnej zmienności na poziomie NTS 3.

** Zmienne dotyczące obciążenia społecznego nie wykazywały żadnej zmienności na poziomie NTS 3.

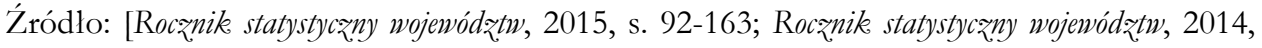
s. 92-163].

Zmienne diagnostyczne do badania poziomu rozwoju społecznego zostały zaproponowane w opracowaniu dla poziomu pomiaru NTS 5 [Gospodarowicz, 2016, s. 9-10], ale ważnym czynnikiem określającym ostateczną zawartość tego zbioru (oprócz przesłanek pozastatystycznych) była ich dostępność na badanym poziomie.

\section{Wykorzystane narzędzia statystyczne i analiza spójności na poziomie NTS 3}

Analizie poddano zmienne diagnostyczne zawarte w tabelach: 2. i 3., opisujące rozwój gospodarczy i rozwój społeczny badanych obiektów - podregionów. Dane 
statystyczne, dostępne w Głównym Urzędzie Statystycznym na poziomie NTS 3, poddano normalizacji, celem doprowadzenia ich do porównywalności [Strahl, 1998, s. 63]. Wszystkie zaproponowane cechy miały charakter stymulant.

Do pomiaru poziomu rozwoju zastosowano bezwzorcową metodę uśredniania zmiennych diagnostycznych, tzw. zmienną syntetyczną [Grabiński, 1992, s.141-143]. Z racji charakteru badania wykorzystano zmienną agregatowa, w której system wag został oparty na miernikach względnej wartości informacyjnej danej cechy diagnostycznej. Waga składowej, tworzącej zmienną syntetyczną, była zatem uzależniona od poziomu zmienności danej cechy. Wobec tego, miernik uzyskany z takiej agregacji był wrażliwszy na zmiany wewnątrz danej cechy. Liczebność zbioru wynosiła 72 obiekty (liczba podregionów).

Tabela 4. prezentuje sposób podziału zbioru podregionów ze względu na poziom rozwoju społecznego i rozwoju gospodarczego.

\section{Reguła dyskryminacji zbioru podregionów}

TABELA 4.

\begin{tabular}{|c|c|}
\hline Poziom rozwoju & Granice \\
\hline I & $(\bar{x}-2 \cdot S ; \bar{x})$ \\
II & $(\bar{x} ; \bar{x}+2 \cdot S)$ \\
III & $(\bar{x}+2 \cdot S ; \bar{x}+4 \cdot S)$ \\
\hline
\end{tabular}

Źródło: opracowanie własne.

Podziału dokonano przy użyciu wartości odchylenia standardowego i średniej. Z uwagi na relatywnie małą liczebność zbioru (liczba podregionów Polski N = 72) dokonano ich podziału na trzy podgrupy.

$\mathrm{Na}$ rysunku 2. zaprezentowano rozrzut empiryczny poziomu rozwoju gospodarczego i poziomu rozwoju społecznego badanych obiektów dla roku 2015.

Histogramy liczebności dla każdej ze zmiennej agregatowej, przedstawione na rysunku 2., zobrazowały grupy o największej liczności w poziomie wartości tych zmiennych. Rozkłady tych cech agregatowych wykazały dużą asymetrię. Z tej racji, że analiza była dokonywana na zbiorze danych zupełnych (72 podregiony) nie traktowano punktów wyraźnie odstających jako obserwacji nietypowych.

Wyraźnie odstaje poziom agregowanych zmiennych dla podregionu $\mathrm{m}$. st. Warszawy. Szczegółowego odpisu przynależności podregionów do określonych grup podobieństw dokonano w kolejnej części artykułu.

W następnym kroku prowadzonej analizy wyodrębniono grupy typologiczne podregionów dla roku 2015.

$\mathrm{Na}$ podstawie rozkładów brzegowych zawartych w tabeli 5. można stwierdzić, że $68 \%$ podregionów miało relatywnie niższy niż średni poziom rozwoju gospodarczego, zaś 28\% średni. Z kolei, 64\% podregionów miało niższy niż średni poziom rozwoju społecznego, natomiast $31 \%$ średni poziom tego rozwoju. 
RYSUNEK 2.

Histogram i rozrzut wartości poziomu rozwoju gospodarczego i społecznego podregionów w 2015 roku

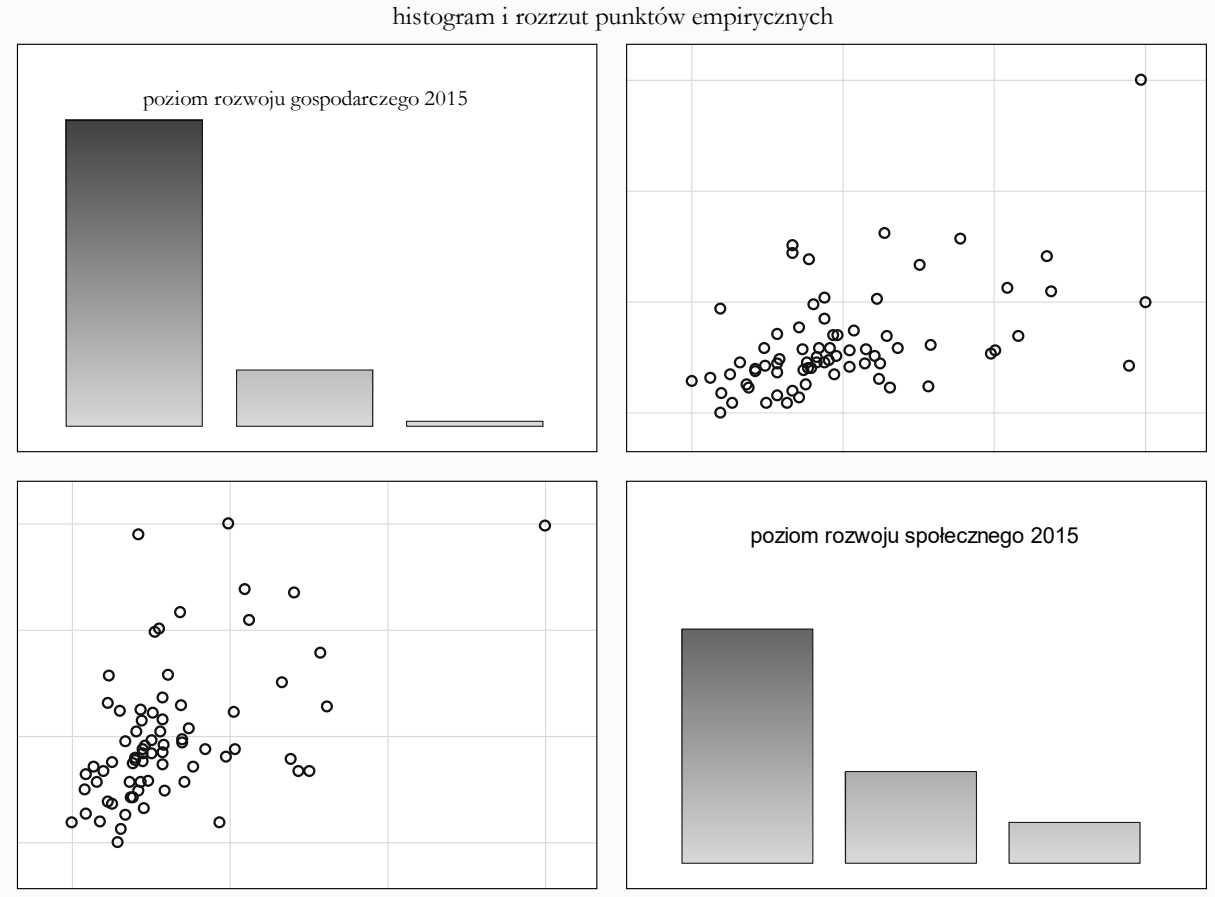

Źródło: opracowanie własne przy użyciu programu Statistica PL.

W tabeli 5. zaprezentowano typologie podregionów ze względu na poziomy wyznaczonych i pogrupowanych zmiennych syntetycznych, określających poziomy rozwoju społecznego i gospodarczego. Utworzono dziewięć grup typologicznych.

TABELA 5.

Typologia podregionów w 2015 roku

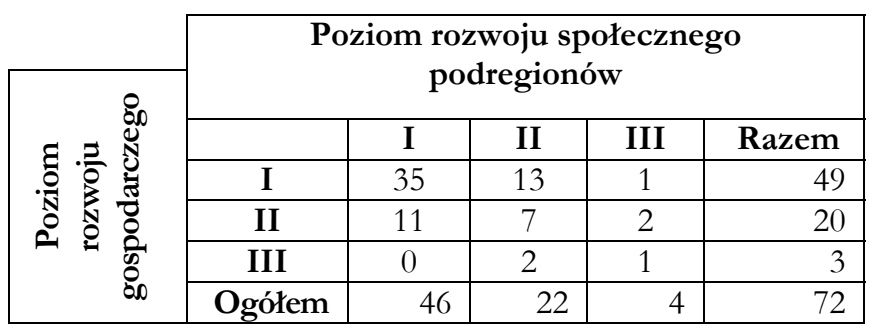

Źródło: opracowanie własne. 
Największą frakcję stanowiły podregiony charakteryzujące się relatywnie niższym niż średni poziomem rozwoju gospodarczego i rozwoju społecznego (35 podregionów - 49\%). Następne, co do liczebności, grupy typologiczne wyróżniała współbieżność w średnim i niższym niż średnia poziomie analizowanych zjawisk (13 podregionów - 18\% i 11 podregionów-15\%). Pozostałe grupy typologiczne cechowała bardzo niska liczebność.

Omawiając wybrane typologie podregionów, należy wyodrębnić (poziom rozwoju gospodarczego i poziom rozwoju społecznego): (III, III) - m. st. Warszawa; (III, II) - m. Poznań, trójmiejski; (II, III) - poznański, warszawski zachodni; (II, II) - warszawski zachodni, bielski, szczeciński, m. Szczecin, m. Wrocław, m. Kraków i tyski; ((II, I) - rybnicki, oświęcimski, radomski, m. Łódź, koniński, sosnowiecki, legnicko-głogowski, katowicki, gliwicki, opolski i płocki; (I, II) - nowotarski, nowosądecki, łódzki, tarnowski, chojnicki, lubelski, białostocki, wrocławski, krakowski, starogardzki, bydgosko-toruński, leszczyński, rzeszowski; (I, III) - gdański. W skład typologii (I, I) weszły pozostałe podregiony.

Zbadano również relację między poziomem rozwoju społecznego a poziomem rozwoju gospodarczego podregionów. Rysunek 3. obrazuje korelacyjny wykres rozrzutu punktów empirycznych.

RYSUNEK 3.

\section{Współbieżność poziomu rozwoju społecznego i gospodarczego} dla podregionów w 2015 roku

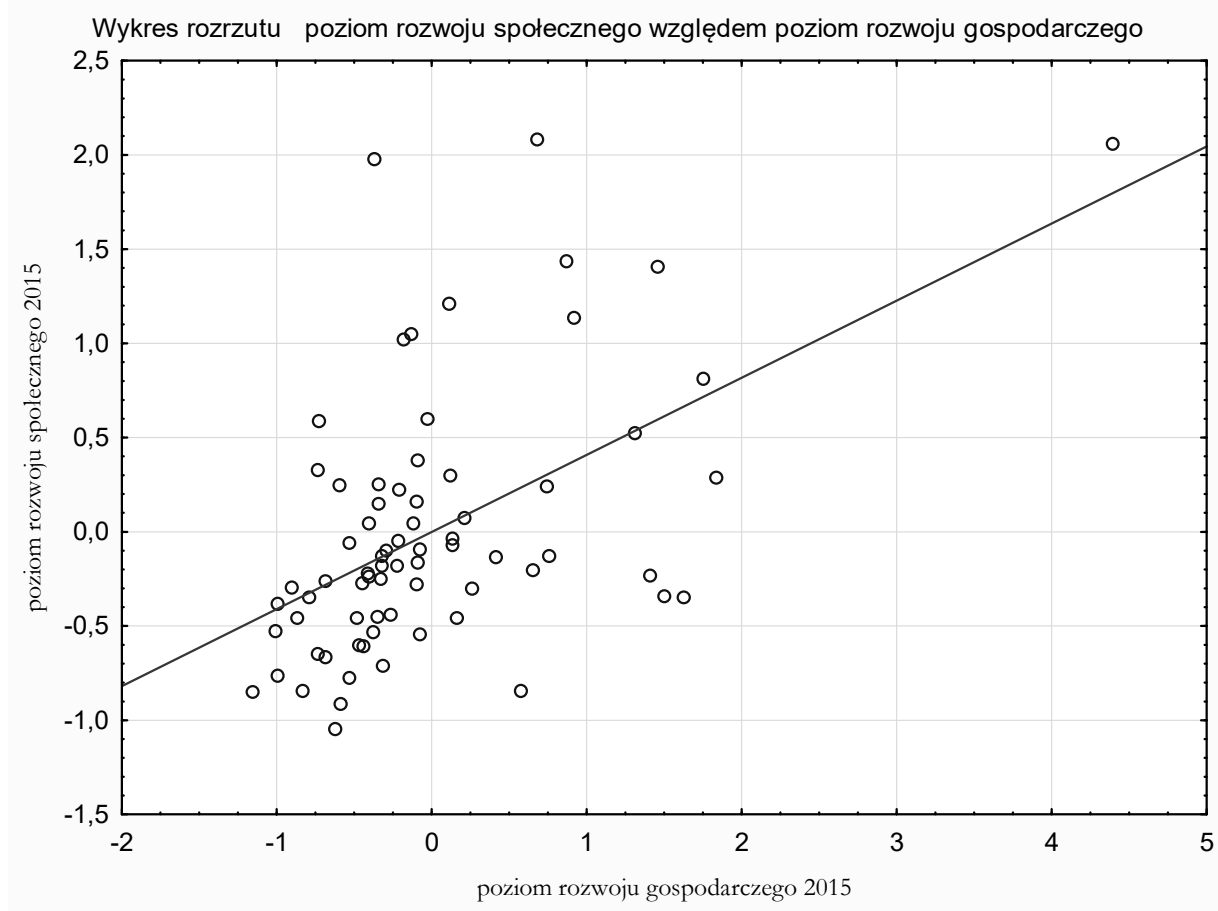

Źródło: opracowanie własne przy użyciu programu Statistica PL. 
Na podstawie rysunku 3. nie można jednoznacznie ocenić, czy badana relacja ma charakter istotny statystycznie. Tabela 6 . zawiera informację, która posłużyła ocenie statystycznej istotności tej relacji.

TABELA 6.

Istotność korelacji poziomu rozwoju społecznego i gospodarczego

\begin{tabular}{|c|c|}
\hline $\begin{array}{c}\text { Współczynnik korelacji liniowej Pear- } \\
\text { sona }\end{array}$ & $\mathbf{0 , 5 1 7 5 1 2}$ \\
\hline $\mathrm{N}=72$ & Korelacja jest istotna $p<0,05$. \\
\hline
\end{tabular}

Źródło: opracowanie własne przy użyciu programu Statistica PL.

Zatem istnieje statystycznie istotna relacja. Dla danego podregionu wyższy (niższy) poziom rozwoju gospodarczego koresponduje z wyższym (niższym) poziomem rozwoju społecznego. Nie jest to oczywiście zależność w formie przyczynowo-skutkowej, a jedynie pewna współbieżność (współistnienie).

RYSUNEK 4.

Współbieżność poziomu rozwoju społecznego i gospodarczego dla podregionów w 2014 roku

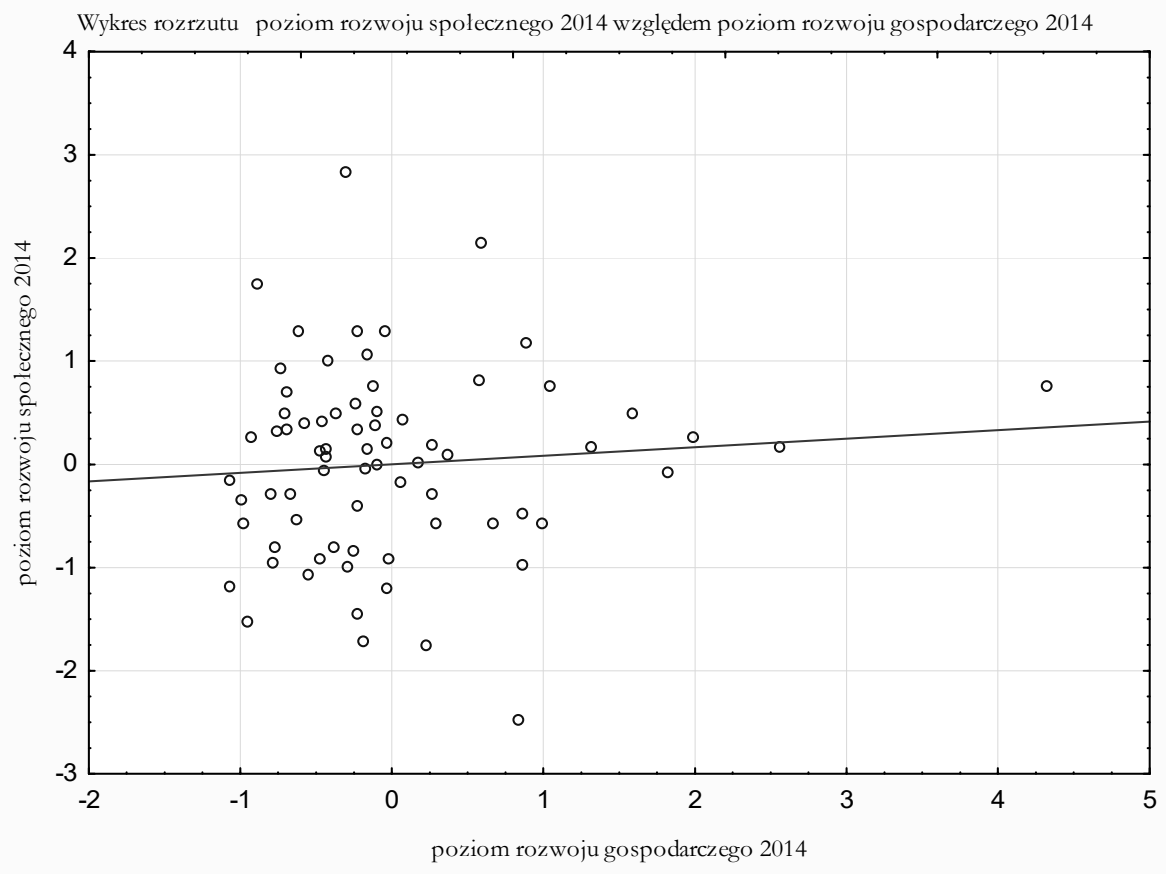

Źródło: opracowanie własne przy użyciu programu Statistica PL. 
Na zakończenie prowadzonej analizy określono zmiany we współbieżności poziomów rozwoju społecznego i rozwoju gospodarczego badanych podregionów na podstawie danych z poprzedniego roku. Było to niewielkie przesunięcie w czasie, ale jedyne, które pozwoliło na wiarygodne porównanie, gdyż nastapiły zmiany w ilości podregionów Polski z 66 obiektów na 72 obiekty. Następnie zbadano relację między poziomem rozwoju społecznego a poziomem rozwoju gospodarczego podregionów w 2014 roku. Rysunek 4. to kolejny, korelacyjny wykres rozrzutu punktów empirycznych.

Tabela 7. zawiera informację, która posłużyła ocenie statystycznej istotności tej relacji dla danych z 2014 roku.

TABELA 7.

Istotność korelacji poziomu rozwoju społecznego i gospodarczego

\begin{tabular}{|c|c|}
\hline Współczynnik korelacji liniowej Pearsona & $\mathbf{0 , 0 8 1 9 8 3}$ \\
\hline $\mathrm{N}=72$ & Korelacja nie jest istotna. \\
\hline
\end{tabular}

Źródło: opracowanie własne przy użyciu programu Statistica PL.

Na podstawie rysunku 4. można jednoznacznie ocenić, że badana relacja nie wykazuje zbieżności. Wartość współczynnika korelacji i brak istotnej statystycznie wartości tego współczynnika potwierdza to spostrzeżenie. Zatem nie istnieje statystycznie istotna relacja. Dla danego podregionu wyższy (niższy) poziom rozwoju gospodarczego nie koresponduje z wyższym (niższym) poziomem rozwoju społecznego. Nie ma istotnej współbieżności, co obrazuje również zawartość tabeli 8.

\section{Typologia podregionów w 2014 roku}

TABELA 8.

\begin{tabular}{|c|c|c|c|c|c|}
\hline \multirow{6}{*}{ 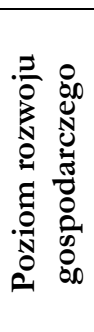 } & \multicolumn{5}{|c|}{ Poziom rozwoju społecznego podregionów } \\
\hline & & I & II & III & Razem \\
\hline & $\mathbf{I}$ & 23 & 25 & 1 & 49 \\
\hline & II & 12 & 5 & 1 & 19 \\
\hline & III & 1 & 3 & 0 & 4 \\
\hline & Ogółem & 33 & 37 & 2 & 72 \\
\hline
\end{tabular}

Źródło: opracowanie własne.

$\mathrm{Na}$ podstawie rozkładów brzegowych zawartych w tabeli 8. można stwierdzić, że $68 \%$ podregionów miało relatywnie niższy niź średni poziom rozwoju gospodarczego, zaś $26 \%$ średni. Z kolei, 45\% podregionów miało niższy niż średni poziom rozwoju społecznego, natomiast 51\% średni poziom tego rozwoju.

Zaprezentowano również typologie podregionów ze względu na poziomy wyznaczonych i pogrupowanych zmiennych syntetycznych, określających poziomy rozwoju 
społecznego i gospodarczego. Utworzono, analogicznie jak dla danych z roku 2015, dziewięć grup typologicznych.

Największą frakcję tworzyły podregiony charakteryzujące się relatywnie niższym niż średni poziomem rozwoju gospodarczego i rozwoju społecznego (23 podregiony - 32\%) i średnim poziomem (25 podregionów - 35\% . Trzecia, co do wielkości, frakcja 12 podregionów stanowiła $17 \%$ i były to regiony o średnim poziomie rozwoju gospodarczego i relatywnie niższym niż średnia poziomie rozwoju społecznego. Pozostałe grupy typologiczne cechowała bardzo niska liczebność.

Omawiając wybrane typologie podregionów, należy wyróżnić (poziom rozwoju gospodarczego i poziom rozwoju społecznego): (III, II) - m. st. Warszawa, m. Wrocław, trójmiejski; (III, I) - m. Poznań; (II, III) - m. Kraków; (II, I) - bielski, lubelski, szczeciński, wrocławski, poznański, płocki, m. Łódź, m. Szczecin, gliwicki, katowicki, tyski, warszawski zachodni; (II, II) - sosnowiecki, opolski, piotrkowski, bydgoskotoruński, legnicko-głogowski; (I, III) - włocławski. Pozostałych 48 podregionów weszło w skład grup typologicznych: (I, I) i (I, II).

Na zakończenie prowadzonej analizy można stwierdzić duże zróżnicowanie w poziomie rozwoju społecznego i w poziomie rozwoju gospodarczego podregionów Polski. Badania współbieżności między poziomem wzrostu gospodarczego a poziomem wzrostu społecznego w 2015 roku wykazały istotna statystycznie zbieżność tych zjawisk. Natomiast analiza danych z 2014 roku nie pokazała istotnej zależności w ich zbieżności.

\section{Podsumowanie}

Analiza zmian w poziomie rozwoju gospodarczego i poziomu społecznego jest ważnym elementem badania spójności podregionów Polski. Zmiany w liczbie podregionów w minionych latach, tzn. wyznaczenie „nowych” podregionów (tabela 1.), tj.: inowrocławskiego i świeckiego w województwie kujawsko-pomorskim, nowotarskiego w małopolskim, płockiego i siedleckiego w mazowieckim oraz chojnickiego w pomorskim, uniemożliwia rozszerzenie tej analizy o dłuższy, wsteczny horyzont czasowy.

Spójność, przez którą rozumie się zbieżność w poziomach zjawisk i niwelowanie zróżnicowania (na poziomie krajowym) oraz wyrównywanie nierówności (na poziomie europejskim), jest ważną kategorią badawcza.

Na podstawie dokonanej analizy można skonstatować, że podregiony Polski charakteryzuje stosunkowo wysoka zbieżność w poziomie rozwoju gospodarczego i poziomie rozwoju społecznego. Relacja tych poziomów wykazuje istotną statystycznie zbieżność, a dane względne obrazują to, że prawie połowę podregionów cechuje zbieżny poziom tych zjawisk. Analiza zmian tej zbieżności w stosunku do roku poprzedniego wskazuje na zmianę (poprawę) tej zbieżności. Przeprowadzona ocena spójności terytorialnej pod względem gospodarczym i społecznym jest punktem wyjścia do dalszych, pogłębionych analiz spójności terytorialnej na poziomie NTS 3. 


\section{Literatura}

Churski P., 2011, Spójność a przestrzeñ - dylematy polityki regionalnej, Biuletyn Instytutu Geografii i Społeczno-Ekonomicznej i Gospodarki Przestrzennej Uniwersytetu Adama Mickiewicza w Poznaniu, „Rozwój Regionalny i Polityka Regionalna”, nr 15.

Faludi A., 2006, From European Spatial Development to Territorial Cohesion Policy, "Regional Studies", vol. 40, no. 6, http://www.tandfonline.com/doi/pdf/10.1080/003434 00600868937? needAccess $=$ true $($ data wejścia: 02.05.2017).

Gospodarowicz M., 2016, Ocena spójności terytorialnej pod wagledem społecznym i gospodarcaym gmin w Polsce, Konferencja IERiGZ̈-PIB Konkurencyjnośc gospodarki w kontekśsie dzৃałań polityki społecznej, Jachranka, https://www.ierigz.waw.pl/download/19554 -prof._dr_hab._M._Gospodarowicz.pdf (data wejścia: 27.04.2017).

Grabiński T., 1992, Metody taksonometrii, Wydawnictwo Akademii Ekonomicznej w Krakowie, Kraków, s. 141-143.

Greta M., Tomczak-Woźniak E., 2016, Problem spójności w nowej polityce regionalnej na lata 2014-2012, http://repozytorium.uwb.edu.pl/jspui/bitstream/11320/968/1/01_ Marianna\%20GRETA.pdf (data wejścia: 31.03.2017).

Growing Regions, Growing Europe. Fourth Report on Economic and Social Cohesion, Komisja Europejska, 2007, Bruksela, http://ec.europa.eu/regional_policy/sources/docoffic/ official/reports/ cohesion4/pdf/4cr_en.pdf (data wejścia: 02.05.2017).

http://stat.gov.pl/statystyka-regionalna/jednostki-terytorialne/nomenklatura-nts/

(data wejścia: 19.06.2017).

https://www.mr.gov.pl/strony/zadania/polityka-rozwoju-kraju/zarzadzanie-rozwojemkraju/kontrakty-wojewódzkie/ (data wejścia: 29.05.2017).

Kontrakt Terytorialny - województwo opolskie, https://www.mr.gov.pl/media/3264/KT_ Opolskie_14112014.pdf (data wejścia: 29.05.2017).

Krajowa Strategia Rozwoju Regionalnego 2010-2020: Regiony, Miasta, Obszary wiejskie, 2010, Ministerstwo Rozwoju Regionalnego, Warszawa, https://www.mr.gov.pl/media/ 3337/KSRR_13_07_2010.pdf (data wejścia: 27.05.2017).

Rocznik statystyczny województw, 2014, GUS, Warszawa.

Rocznike statystyczny wojewódzৃtw, 2015, GUS, Warszawa.

Rynio D., 2012, Regiony problemowe wobec nowego paradygmatu polityki regionalnej w Polsce, [w:] Problemy rozwoju regionalnego, E. Sobczak, A. Raszkowski (red.), Prace Naukowe Uniwersytetu Ekonomicznego we Wrocławiu nr 244, Wydawnictwo Uniwersytetu Ekonomicznego we Wrocławiu, Wrocław.

Strahl D., 1998, Taksonomia struktur w badaniach regionalnych, Wydawnictwo Akademii Ekonomicznej we Wrocławiu, Wrocław. 